\title{
Testing The Moderating Effect of the Strategy on the Relationship between Human Resources Management and Performance: A Subgroup Analysis. The Case of Tunisia
}

\author{
Hamid JERY \\ Associate professor, FLSHK, University of Kairouan, Tunisia \\ Tel: 216-9790-6207_E-mail: hamidjari@yahoo.fr
}

Saloua SOUAÏ

Associate professor, ISCCB, University of Carthage, Tunisia

Tel: 216-9790-6207Ｅ-mail: salouadoct@yahoo.fr

Received: March 1, 2016 Accepted: March 15, 2016 Published: May 3, 2016

doi:10.5296/bms.v7i1.9130 URL: http://dx.doi.org/10.5296/bms.v7i1.9130

\begin{abstract}
In a fast movement environment where organizations are struggling to survive and succeed in the market, the focus is increasingly placed on resources that can provide a sustainable competitive advantage. Wright, McMahan and McWilliams (1994), like other researchers have realized that human resources can generate this advantage since they are rare, difficult to substitute and imperfectly imitable. The more human resources are exploited and the more they get enriched and provide added value to the organization through creativity and innovation.

We note that the prerequisite for the added value creation is individual motivation and competence at work. Thus, it is assumed that the development of human resources management enables to meet the competitiveness challenge. Human resources managers have to enhance staff motivation and to ensure continuous knowledge improvement.
\end{abstract}


In this research, we try to explain the link between the human resource management practices and performance through the contingency approach. To do this, we opt for the subgroup analysis as a methodological framework. Our results lead to recognize that the interaction effect between certain human resource management practices and innovation level can provide an explanation as to changes in the level of performance of the Tunisian industrial firms.

Keywords: Strategy, Human resource management, Performance, Subgroup analysis, Contingency approach 


\section{Introduction}

The environment continuous movement is pushing firms to restructure and to continually take adjustment measures. The adaptation quest enables organization to survive and to stay as long as possible on the market. To this end, human resources managers are doing their best to meet the competitiveness challenges and try to focus on the human resources development and motivation by adopting human resource management (HRM) practices. Motivated individuals demonstrate effectiveness, seek to invest in their work and exhibit organizational citizenship behaviors. Many researchers (Delaney, Lewin and Ichniowski, 1989; Huselid, 1995; Osterman, 1994; Pfeffer, 1994; Guérin, Wils and Lemire, 1997 Delery and Doty, 1996; Youndt, Snell, Dean and Lepak 1996 ...) examine the impact of certain HRM practices on business performance.

However, we note that HRM practices differ from one author to another. This observation brings us directly to the questioning about the contingency or the universality of these practices. The contingency approach is based on the principle of the context uniqueness. Therefore, to explain an organizational phenomenon, it is important to address, to the last detail, the situational specifics and peculiarities generated by such a context. The contingency approach is categorically opposed to the Universalist approach. This latter acknowledges the existence of certain HRM practices that are always better than others for a better performance and all organizations should adopt these practices called: best practices, regardless of their context.

From the contingency perspective, some variables are supposed to have an influence on the productivity and performance. From a methodological point of view, the contingency approach highlights the manner that the relationship between dependent and independent variables is affected, much or little, by a third variable called contingency variable (Pugh and al., 1969). Transposed in the HRM field, the contingency approach emphasizes that HRM practices can have a positive effect on performance when aligned with a contingency variable such as: the firm's strategy (Dyer 1984; Lengnick Hall and Lengnick-Hall, 1988, 2013; Miles and Snow, 1984; Fombrun and al., 1984; Youndt, Snell, Dean and Lepak, 1996).

\section{Literature Review}

\subsection{The Contingency Approach in the Human Resource Management Field}

The contingency approach postulates that the positive effects of HRM practices on performance are better perceived in the case of the aligning of human resource practices on the corporate strategy. Hence, the basic idea of the contingency approach lies in the contextualization of HRM policies and practices. At this stage, we can postulate that the HRM efficiency is dependent on its consistency with the strategic direction of the firm (Dyer, 1984; Lengnick Lengnick Hall and Hall, 1988; Miles and Snow, 1984; Fombrun and al., 1984; Youndt, Snell, Dean and Lepak, 1996).

The contingency approach refutes the idea of universality and finds unacceptable that 
practices can be applied in any context and at any time. Instead, it considers it essential to try to understand each situation, each environment, identify specific characteristics and propose customized solutions. These characteristics considered as contingent variables may include the organization age, the organization size, the technical system, the environment, the power relations (Mintzberg, 1980), the strategy (Chandler, 1962), the technology (Woodward, 1968) and the goals (Lawrence and Lorsch 1967). According to the contingency approach, a practice can only be effective when taking into account the different contingent variables of a given situation.

In this paper, we focus on the strategy and more specifically on the firm's innovation level as a contingent variable in order to examine the relationship between certain HRM practices and business performance.

The contingency approach, as it were, advocates the principle of alignment or external fit between strategy and HRM practices in order to improve its performance and get better results.

Several studies on the relationship between HRM practices and strategy admit the preeminence of the behavioral approach of human resources in explaining the contingency theory (Delery and Doty, 1996; McMahan, and Wright Virick, 1999; Schuler and Jackson, 1987). Thus, an organization can succeed if only it has employees whose behaviors are going into the same direction as the business strategic requirements (Katz and Khan, 1978; Schneider, 1985).Then, it becomes interesting to focus more on the HRM, since it encourages and incites satisfying organizational behavior (Schuler and Jackson, 1987; Delery and Doty, 1996). HRM can play an important role in reinforcing appropriate behavior, and this, according to the behavioral theory which states that for every strategy there are specific behaviors.

Miles and Snow (1978) propose a firms typology in terms of strategy, and technical, structural and process configuration. Based on case studies in four different sectors (school edition, electronics, food industry and health), these authors distinguished three basic firms type: prospector type, analyzer type, and defender type. We briefly present the characteristics of each firm type as developed by Miles and Snow.

Prospectors are growth-oriented firms who exploit the markets' opportunities by means of their innovation capabilities and who try develop new products. These prospector firms are driven by the desire to be a leader in new markets. These firms do have an organic structure, complex and changing tasks and operate in an unsteady environment.

Defender type firms are characterized by a highly formalized and centralized functional structure. Performance is, here, defined in terms of cost control rather than in terms of market results. Firms operate in a stable environment and offer stable tasks. They discourage the behaviors involving risk-taking since the already-made investments in technology and existing processes are important. 
Finally, the analyzer type firms share some characteristics with the defender and prospector firms. The analyzer firms adopt an intermediate position between minimizing risk and optimum profitability of business opportunities.

\subsection{Hypothesis}

- Firms with high levels of innovation (prospector type) and that focus more on some HRM practices will achieve better performance levels.

- Firms with average level of innovation (analyzer type) and that focus more on some HRM practices will achieve better performance levels.

- Firms with low levels of innovation (defender type) and that focus more on some HRM practices will achieve better performance levels.

- Firms (prospector type, analyzer type and defender type) do not adopt all the same practices of HRM.

\section{Methodology}

In the context of this research, we have reached a judgment sample composed of 114 industrial firms. These firms are selected based on criteria considered as relevant for the investigation purpose.

- The selection criteria are:

- $\quad$ ISO 9001 certification

- $\quad$ Firm age $>3$ years

- Regime: not totally exporting.

\subsection{Variables Measurement}

The independent variable in this study is the set of strategic practices of HRM including: selection, training, incentive compensation, information sharing, participation in decision-making and performance appraisal.

Selection: seven items adapted from works of Dean and Snell (1992) and Arcand (2007).

Training: seven items inspired from the scales of Snell and Dean (1992) and Arcand (2007).

Participation in decision making: scale work inspired from Arthur (1992, 1994); Lawler and al., (1992) and Fabi and al. (2007).

Incentive Compensation: 7 items inspired from the instruments developed by Gomez-Mejia (1992), Lawler and al. (1992) and Tremblay (1994).

Information sharing: 6 items used by Simard and al. (2005).

Performance appraisal: eight items inspired from the scales of Snell and Dean (1992) and 
Delery and Doty (1996).

The dependent variable in our study is the performance in a multidimensional perspective of measures. These measures are subjective and are recommended as substitutes when quantitative data are unavailable (Venkatraman and Ramanujan, 1986).

This kind of subjective measures is well suited in the research of HRM, and moreover, a strong convergent validity is demonstrated between objective and subjective measures, as is the case in the financial reports (Venkatraman and Ramanujam, 1986).

We keep the same logic for the performance criteria selection and we choose 12 items used in previous researches (Huselid, 1996; Arcand, 2007). The first five items measure human resources performance. The following four items measure organizational performance and the last three are related to financial performance.

Finally, and concerning the moderating variable, we adopt a nominal measure of the firm's strategy adapted from the survey of "Cranifield Network on Comparative Human Resource Management" (Cranet, 2004). In accordance with the qualitative approach, the manager is asked to choose, among the following statements, the one that best describes his business strategy:

- Prospector: You intervene in a changing market. Your objective is to identify and exploit new opportunities through innovation (products or services) in order to meet the new identified needs.

- Defender: You intervene in a mature and stable market. You aim maintaining your market share through improved productivity, lower costs and a medium and long term planning.

- Analyzer: you work both in stable and turbulent markets. You aspire to mitigate risk while delivering new products and/or services. Your purpose is to maintain your position in existing markets and to identify new opportunities in new markets.

\subsection{Hypothesis Testing Approach}

In order to test our hypotheses, we consider that the moderator variable is qualitative (nominal). According to Chumpitaz Caceres and Van Hamme (2003), if the moderating variable is measured on a nominal scale, it's appropriate, firstly, to regress $\mathrm{Y}$ on $\mathrm{X}$ for each subgroup of subject, that correspond to the different modalities of the nominal variable and secondly to compare, two by two, the obtained regression models. We have just to prove that any of these comparisons is statistically significant to highlight a moderating effect. "Before performing this type of analysis by subgroups, however, this is to ensure beforehand that the underlying conditions to statistical tests used-such as the homogeneity of variance for the different levels of moderating variable are met "(Chumpitaz Caceres and Vanhamme J, 2003, p 81).

At this analysis level, we act in two stages. First, we test the effect of HRM practices on the 


\section{Macrothink}

three performance levels in each subgroup. Second, we compare results stemming from the first step.

The three subgroups analyzed in our work are:

- The prospector type firms: highly innovative firms $(\mathrm{N}=32)$

- Defender type firms: weakly innovative firms $(\mathrm{N}=34)$

- Analyzer type firms: averagely innovative firms $(\mathrm{N}=48)$

Before beginning this analysis, we have to ensure the homogeneity of variances from the hypothesis concerning the three levels of the moderating variable (contingency) is really respected:

$\mathrm{H} 0:=\sigma_{2}^{2}=\sigma_{3}^{2}=\sigma_{3}^{2}$

H1 $\sigma_{1}^{2}$ or $\sigma_{2}^{2}$ or $\sigma_{3}^{2}$ not equal (s)

Statistics Levene $($ HR Performance $)=0.337 ; p=0.7347>0.05$

Statistics Levene $($ Organizational Performance $)=0.672 ; p=0.734>0.05$

Statistics Levene $($ Financial Performance $)=1.047 ; p=0.355>0.05$

\section{Results and Discussion}

\subsection{Strategic HRM Practices - Strategy- Performance: Regression Subgroup Analysis}

The prospector type firm operates in a changing market. Its primary aim is to redefine its field of activities and to seek continuously to develop a commercial action. Thus, the objective is to identify and exploit new opportunities through innovation, and to cope with the changing environment.

In the following, we present the test results of the HRM practices effect on the performance three levels in firms that opt for a prospector strategy. In terms of human resources performance, the results springing from statistical analyzes show that, among the six enumerated practices, only the information sharing does not contribute significantly to this performance level $(\beta=-0.086 ; F=0.396 ; p$-value $>0.1)$.

Statistics indicate that organizational performance in highly innovative firms is experiencing growth as a result of some specific practices such as: selection, performance appraisal. Indeed, the statistical analyzes about selection, clearly show the link significance between this practice and organizational performance $(\beta=0.463 ; \mathrm{F}=2.444 ; 0.01<\mathrm{p}$-value $<0.05)$. The same results are found for performance appraisal, also, the statistical analyzes show clearly the significance of the relationship between this practice and organizational performance $(\beta=$ $0.429 ; \mathrm{F}=2.110 ; 0.01<\mathrm{p}$-value $<0.05)$. 
Finally, we find out that three HRM practices can increase the financial performance level in the prospector type firm, it's about: selection, participation in decision-making and performance appraisal. Thus, we note that there is a significant relationship between selection and the firm's financial performance. Statistical analyzes indicate that highly innovative firms who attach great importance to the staff selection display a better financial result than other firms $(\beta=0.455 ; \mathrm{F}=2.730 ; 0.01<\mathrm{p}$-value $<0.05)$. As to the relationship between participation in decision-making and financial performance within the prospector type firm, the results of our survey proves the existence of a significant link. Statistical analyzes related to this practice show clearly the significance of the relationship: $\beta=0.337 ; \mathrm{F}=1.549 ; 0.05$ $<\mathrm{p}$-value $<0.1$. For performance appraisal, the results point out that this practice is positively related to financial performance $(\beta=0.331 ; \mathrm{F}=1.655 ; 0.05<\mathrm{p}$-value $<0.1)$. So the more the firm attaches importance to the performance appraisal, the more its financial performance will be better.

The defender type firm operates in a mature and stable market. It acts in a well-defined and stable activity domain in order to achieve a leading position in terms of quality and / or price. The main objective is to maintain its market share especially by improving productivity, reducing costs and ensuring a medium and long term planning. The defender type firm aspires to get HRM practices which relate positively to performance under the three angles. Among the HRM practices adopted in this research, statistical analyzes indicate that four practices contribute positively to human resources performance in the defender type firm. These practices include training, incentive compensation, information sharing and performance appraisal. Thus, our results underline the significant links between these four practices and human resource performance as dependent variable.

For organizational performance, analyzes of regressions give us similar results to those relating to the human resources performance. Indeed, training, incentive compensation, information sharing and performance evaluation, contribute positively to organizational performance defender type firms. When the defender type of firm attaches importance to training, incentive compensation, in information sharing and performance evaluation, it displays a better organizational performance.

Lastly, and concerning the third level of performance, our results indicate that the six practices adopted in this work contribute positively to financial performance. Indeed, the regressions show that there are statistically significant links between each of these HRM practices and financial performance.

The analyzer type firm is operating within many markets: some are stable, others are continuously changing. This firm seeks to exploit new opportunities while maintaining a stable business base. Its objective is to preserving its position in existing markets and to identifying new opportunities in new markets. In this working paper, we are trying to test the potential influence of HRM practices on the performance three levels in the analyzer type firm. Thus, we proceed to the same analyzes as for the other two types of firm. 


\section{Macrothink}

The results show a positive correlation only for two HRM practices and human resources performance in moderately innovative firms. Thereby, statistical analyzes demonstrate a statistically significant relationship between human resource performance as a dependent variable and the selection practice level of implantation. These analyzes indicate that information sharing is positively related to this performance level.

The results relative to the analyzer type firm reveal that investment in incentive compensation and information sharing allows the organizational performance increase. Indeed, Statistical tests for these two variables are significant since the probability of exceeding test is $0.001<\mathrm{p}$ $=0.01$ for sharing information and $0.064<\mathrm{p}=0.1$ for incentive compensation.

Also, results prove the existence of a positive relationship between some HRM practices and financial performance. Based on this observation, the incentive compensation and information sharing can be seen as strategic variables in moderately innovative firms. Statistical analysis evince the role of these practices in increasing significantly the financial performance level in the analyzer type firms $(\beta=0.497 ; \mathrm{F}=3.868$; $\mathrm{p}$-value $<0.01)$ for sharing information and $(\beta=0.290 ; \mathrm{F}=1.455 ; 0.05<\mathrm{p}$-value $<0,1)$ to incentive compensation.

\subsection{Empirical Evidence of the Moderating Effect of Strategy}

Once our results are presented for each type of firm, we conduct verification in order to highlight the moderating effect of business strategy on the relationship between HRM practices and firm performance. We compare two by two, the regression models obtained. If we show that one of these comparisons is statistically significant then we will be able to prove the existence of a moderating effect.

The moderating effect analysis allows testing the existence of a significant difference at level of non-standardized coefficients of group regression (Baron and Kenny, 1986). In other words, we have to test the significance of the following t test (Hardy, 1993, cited by Chumpitaz and Vanhamme, 2003).

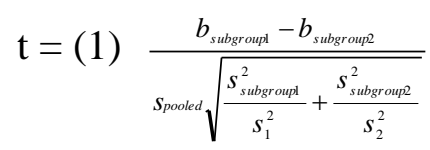

Where:

$b_{\text {subround }}$ and $b_{\text {subgoup } 2}$ : estimates of regression coefficients of the variable $\mathrm{X}$ for the subgroups 1 and 2.

$s_{b_{\text {subgroupl }}}^{2}$ and $s_{b_{\text {subroun }}}^{2}$ : the variance of these coefficients

$s_{1}^{2}$ and $s_{2}^{2}: S C R / n-k-1$ and: for every group (RSS is the residual sum of squares and 
$R S S / n-k-1$ corresponds to the residual mean square and, $\mathrm{k}:$ the number of independent variables.

$s_{\text {pooke }}^{2}$ Corresponds to the equation (2).

$\frac{\left(n_{1}-k_{1}\right) s_{1}^{2}+\left(n_{2}-k_{2}-1\right) s_{2}^{2}}{N-\left(k_{1}+k_{2}+2\right)}$

Where: $N=n 1+n 2$

According to Chumpitaz and Vanhamme (2003), and in order to conclude that there is a moderating effect, the t-test has to be significant in at least one case.

- Comparison two by two of coefficients according to (1) and (2) for the human resources performance

The tests $t$ calculation according to the formulas (1) and (2) shows that there are six differences which are significant, two by two. So there is a moderation effect of the firm's business strategy on the relationship between HRM practices and HR performance.

- Comparison two by two of coefficients according to (1) and (2) for the organizational performance

Regarding organizational performance, test results indicate that the business strategy has a moderating effect on the relationship between HRM practices and performance level. Thus, the $t$ test calculation shows that there exist four differences which are significant, two by two.

- Comparison two by two of coefficients according to (1) and (2) for the financial performance.

The $t$ test calculation for financial performance shows that this test is significant in three cases. Thus, we can confirm the existence of a moderating effect of the firm's strategy on the relationship between HRM practices and financial performance.

According to the foregoing, we can advance that the results of our research constitute an important support that validate the contingency approach in the studied context. Indeed, analysis by subgroups allowed us to confirm the assumptions related to the perspective of the HRM contingency, so we can draw the following conclusions:

Among the prospector type firms (highly innovative), those that invest more in the selection, training, incentive compensation, participation in decision-making and performance evaluation have performed better.

Similarly defender type firms (weakly innovative) that opt for greater investment in the selection, incentive compensation, training, participation in decision making, information 
sharing and performance evaluation have realized better performance

Finally, with regard to analyzer type firms (innovative medium), those that invest more in the selection, incentive compensation and information sharing have better performance.

These results allow us to confirm the hypothesis that there are differences between HRM practices adopted by each type of firm (prospector, analyzer, and defender) and their impact on performance.

\subsection{Discussion}

A prospector type firm wishing to boost innovation and creativity can only rely on its human resources management and especially on its HRM practices. This research has allowed us to find results stating that the preferred HRM practices for the prospector type firm are: the selection, training, incentive compensation, participation in decision making and evaluation of performance. Thus, companies that invest in these practices can ensure better performance. Hence, it is important to refine the selection methods when hiring. The Proficient managers should be able to choose the right person by favoring the criteria ranking candidates according to their qualifications, to their experience but also to their "know-how-to-be". The latter criterion seems in vogue these recent years, given its importance in determining individual traits and their impact on attitudes and behavior at work. Being: able to evolve, at ease dealing with change, self-controlled, sociable, able to coping with the unexpected are key indices of candidate competencies. Conduct successfully the step of selecting staff, allow firms to recruit endowed individuals with a competitive spirit and who appreciate the adventure, the risk-taking and the creativity.

Should be noted that, in a change context, firms have also to focus on the existing staff by promoting learning through professional mobility, job rotation, and continuous training. Furthermore, it is to consider that incentive compensation is central in the HRM of prospectors firms. Premiums, bonuses, stock options, fringe benefits..., incite staff to be motivated and let them work hard in order to achieve their goal. Other important point for these firms is to encourage participation in decision making. Individuals, involved in the decision process, see increasing their self-esteem and aspire to more responsibilities.

Performance evaluation constitutes another HRM crucial practice, as proved by the research results. It allows employees to compete against other and to assess their own efforts. Thus, firms must establish objective criteria and prioritize transparency and justice in judgments. This fair assessment enables some persons to overcome their faults, and help others, those searching for emulating, to seek for continuous improvement.

In regards to analyzer type firms called moderately innovative firms, our research results indicate it's necessary to adopt a different and appropriate set of HRM practices. This set of practices includes selection, training, incentive compensation, participation in decision making, information sharing and performance evaluation. The firm needs competent staff, so it is recommended to alternate between internal and external recruitment as required by the 
environment. If the environment is stable, internal recruitment will certainly constitutes a real boon to staff in strengthening the organizational affiliation and the corporate culture and in privileging promotions. In a changing environment, it is judicious to prefer external recruitment. The new recruits' integration may dynamize the work by adding some "new blood" in order to bring in new ideas, principles and values.

Training enables both updating and increasing knowledge but also motivating staff. These latter are aware about the firm's interest towards them and are able to sense the firm's willingness to meet their requirements. Incentive compensation appears also to play a key role in motivating staff. Thus, if an employee can receive compensation at the height of his contributions, he will increase his efforts to achieve organizational goals. Concerning participation in decision making, it is clear that employees can be proud and satisfied when feeling involved in the decision-making process either in stable or changing environment. Also, it must be added that the diffusion of the sharing information idea among the firm members allows to strengthening ties firstly between all employees and secondly between employees and their supervisors. The motto of any successful business is the exchange and information sharing. Finally, we can consider the performance appraisal as an interesting practice for the analyzer type firm when the evaluation obeys to objective, fair and transparent criteria.

As regards the defender type firms, our research results highlight three HRM practices that improve performance: selection, incentive compensation and sharing of information. It is a question, for the firm, to refine its selection techniques in order to find suitable candidates for the posts and to make up the missing profiles and bridge the gap in skills. The defender type firm can count on staff to improve performance by using the monetary motivation in order to get employees to voluntarily work more and better. Another decisive HRM practice is the information sharing: The sharing culture has proved successful these later years, especially within project teams. It is crucial in these cases to foster interpersonal communication and information exchange. Cooperation constitutes the key to success and prosperity for every firm. It is manifested essentially through mutual aid, solidarity and information sharing. All the firm members will unite their efforts to work in harmony and allow the defender type firm to improve its performance.

\section{Conclusion}

In this research we have tried to identify the specific HRM practices necessary to each type of business strategy and that lead to significant results in terms of performance. More specifically, we sought to test the moderating effect of business strategy on the relationship between the HRM practices and the performance. This latter is seen from different angles that are human resources performance, organizational performance and financial performance. With regard to the business strategy, we retained: the prospector type firms that emphasize innovation, the analyzer type firms that encourage innovation and the defender type firms that manifest little interest in innovation. The search findings result from an original statistical analysis of the research model advocated. The subgroup analysis allowed us to specify for 
each group of firms having a particular strategy, the suitable HRM practices that help achieving high performance levels. Miles and Snow (1978) have also developed proactive HRM systems that are consistent with the business strategy.

Concerning the prospector type firms, where innovation is paramount, the HRM practices fostered are: selection, training, incentive compensation, and participation in decision-making and performance assessment. These firms need to acquire qualified personnel (selection), they must ensure and facilitate learning and continuous improvement of knowledge (training). With a view to engage and motivate employees there is no better than incentive compensation. In addition, helping employees participate in decision-making will reinforce their self-esteem and lead them to work hard, to be creative and innovative. Finally, a performance appraisal transparent system is necessary for guaranteeing fair and objective employees' treatment.

Regarding the analyzer type firms that adopt a moderately innovative strategy, a set of specific HRM practices is adopted for better performance. These practices are: selection, training, incentive compensation, participation in decision making, information sharing and performance evaluation. These firms need competent staff so; they proceed to external recruitment and favor a rigorous selection. Firms can also develop training programs for existing staff. The pecuniary motivation and the information sharing are central in this type of firm: This has a positive effect on the decisions efficiency. Finally, this firm type has to develop a performance evaluation objective system by ensuring the procedural justice.

Finally, for the defender type firms, characterized by a weakly innovative strategy, managers seek to get a skilled workforce through motivation by granting incentive compensation and promoting sharing information. This will help firms to ensure their functioning and survival without investing a lot in human resources.

To conclude, we can say that the research results prove that the interaction effects between certain HRM practices and the innovation level can explain the performance variations in the Tunisian industrial firms. The contingency approach is an interesting approach of HRM in that it highlights the specificity of each organizational context and promotes a specific HRM model for each case.

\section{References}

Arcand M., Arcand G., \& bayad M. (2004). Systèmes de gestion de RH et performance organisationnelle. Annals of public and cooperative Economics, 75(3), 497-524. http://dx.doi.org/10.1111/j.1467-8292.2004.00260.x

Arcand M., Arcand G., \& Moreau É. (2002). Le rôle de la gestion des ressources humaines dans le développement des caisses populaires des jardins du Québec: une validation de l'approche universaliste des ressources humaines, XXVIIIème Colloque annuel de l'Association de science régionale de langue française (Trois-Rivières, Québec, Canada).

Arcand, G. (2007). Étude du rôle de la culture nationale dans la relation entre les pratiques de GRH et la performance organisationnelle: le cas des banques de vingt-deux pays 
d'Amérique du Nord, d'Europe et d'Asie. Thèse de doctorat en sciences de gestion, sous la direction de Bayad M, Université Paul-Verlaine, 306p

Arthur, J. B. (1992). The Link between Business strategy and Industrial Relations systems and American steel Minim ills. Industrial \& Labor Relations Review, 45(3), 488-406. http://dx.doi.org/10.1177/001979399204500306

Arthur, J. B. (1994). Effects of Human Resource systems on manufacturing performance and turnover. Academy of Management Journal, Jun, 37, 670-687. http://dx.doi.org/10.2307/256705

Barkema, H. G., \& Gomez-Mejia, L. R. (1998). Managerial compensation and firm performance: A general research framework. Academy of management journal, 41(2), 135-145. http://dx.doi.org/10.2307/257098

Baron, R. M., \& Kenny, D. A. (1986). The moderator-mediator variable distinction in social psychological research: conceptual, strategic and statistical considerations. Journal of $\begin{array}{llrl}\text { Personality } \quad \text { and Social } & \text { Psychology, } & \text { 51(6), }\end{array}$ http://dx.doi.org/10.1037/0022-3514.51.6.1173

Barrette, J., \& Simeus, M. (1997). Pratiques de gestion des ressources humaines et performance organisationnelle dans les entreprises de haute technologie. Actes du congrès annuel de la section Ressources humaines de l'Association des sciences administratives du Canada, 18(9), 23-33.

Becker, B., \& Gerhart, B. (1996). The impact of human resource management on organizational performance: progress and prospects. Academy of Management Journal, 39(4), 779-801. http://dx.doi.org/10.2307/256712

Chandler, A. (1962), Strategy and Structure: Chapters in the history of industrial enterprise, Doubleday, New York.

Chumpitaz Carceres. R., \& Vanhamme J. (2003). Les processus modérateurs et médiateurs: distinction conceptuelle, aspects analytiques et illustrations. Recherche et Applications en Marketing, 18(2), 67-100. http://dx.doi.org/10.1177/076737010301800204

Delaney, J., Lewin, D., \& Ichniowski, C. (1989). Human Resource Policies and Practices in American Firms. Washington, DC: U.S. Government Printing Office.

Delaney, J. T., Lewin, D., \& Ichniowiski, C. (1989). Human Resource Policies and Practices in American Firms. Bureau of Labor-Management Relations, 137.

Delery, J., \& Doty, D. (1996). Modes of theorizing in strategic resource management: Tests of Universalistic, contingency and configurational performance predictions. Academy of Management Review, Aug, 39, 802-835.

Delery, J. E. (1998). Issues of fit in strategic human resource management: implications for research. Human Resource Management Review, 8(3), 289-309. 
http://dx.doi.org/10.1016/S1053-4822(98)90006-7

Fabi, B., Raymond, L., \& Lacoursière, R. (2007). La GRH, levier du développement stratégique des PME. Revue de Gestion des Ressources Humaines, 65, 41-56.

Gerhart, B., \& Rynes, S. L. (1990). Interviewer Assessments and Applicants «fit»: An Exploratory Investigation. Personnel Psychology, 43, 75-86.

Gomez-Mejia, L. R. (1992). Structure and process of diversification, compensation strategy, and firm performance. Strategic Management journal, 13(5), 381-397. http://dx.doi.org/10.1002/smj.4250130506

Guérin, G., Wils, T., \& Lemire, L. (1997). L'efficacité des pratiques de gestion des ressources humaines: Le cas de la gestion des professionnels syndiqués au Québé. Relations Industrielles, 52(1), 61-90.

Lawler, E. E., \& Jenkins, G. D. J. R. (1992). Strategic reward systems. Handbook of industrial and organizational psychology, 16, 1010-1055.

Lawler, E. E. (1992). The Ultimate Advantage: Creating the High Involvement Organization. San Francisco, CA: Jossey-Bass.

Lawrence, P., \& Lorsch, J. (1967) Organization and Environment: Managing Differentiation and Integration. Harvard University.

Lengnick-Hall, C. A., \& Lengnick-Hall, M. L. (1988). Strategic Human Resource Management: A Review of the Literature and Proposed Typology. Academy of Management Review, 13(3), 454-470.

Lengnick-Hall, C. A., Lengnick-Hall, M. L., \& Rigsbee, C. M. (2013). Strategic human resource management and supply chain orientation. Human Resource Management Review, 23, 366-377. http://dx.doi.org/10.1016/j.hrmr.2012.07.002

Liouville, J., \& Bayad, M. (1995). Stratégies de gestions des ressources humaines et performances dans les PME: résultats d'une recherche exploratoire. Gestion 2000, 1, 159-179.

Miles, R., \& Snow, C. (1984). Designing strategic human resource systems. Organization Dynamics, 13(1), 36-52. http://dx.doi.org/10.1016/0090-2616(84)90030-5

Miles, R., Snow, C., Meyer, A., \& Coleman, J. R. (1978). Organizational strategy; structure, and process. Academy of management review, 546-562.

Mintzberg, H. (1980). Structure in 5's: A Synthesis of the Research on Organization Design, Management Science, 26(3), 322-341. http://dx.doi.org/10.1287/mnsc.26.3.322

Morishima, M. (1991). Information Sharing and firm performance in Japan. Industrial Relations, 30(1), 37-61. http://dx.doi.org/10.1111/j.1468-232x.1991.tb00774.x 
Osterman, P. (1994). How common is workplace transformation and who adopts it? Evidence from a National Survey. Industrial and Labor Relations Review, January. http://dx.doi.org/10.1177/001979399404700202

Pugh, D., Hickson, J., Hinings, R., \& Turner, C. (1969). The context of organization structures. Administrative Science Quarterly, 14, 91-114. http://dx.doi.org/10.2307/2391366

Simard, G., Doucet, O., \& Bernard, S. (2005). Pratiques en GRH et engagement des employés: le rôle de la justice. Relations Industrielles, 60(2), 296-319. http://dx.doi.org/10.7202/011723ar

Snell, S., \& Dean, J. (1992). Integrated Manufacturing and HRM: A Human capital perspective. Academy of management Journal, 35, 292-327. http://dx.doi.org/10.2307/256375

Tremblay, M., \& Wils, T. (2005). La mobilisation des ressources humaines: une stratégie de rassemblement des énergies de chacun pour le bien de tous. Gestion, 30(2), 60-68. http://dx.doi.org/10.3917/riges.302.0060

Venkatraman, N., \& Ramanujam, V. (1986). Measurement of business performance in strategy research: a comparison of approaches. Academy of Management Review, 11(4), 801-814.

Wright, P. M., McMahan, G. C., \& Virick., M. (1999). Alternative theoretical perspective for strategic human resource management revisited: progress, problems, and prospects. in P.M. Wright \& al. (dir.), Research in Personnel and Human Resources Management, Supplement 4, London, JAI Press, 99-122.

Wright, P. M., McMahan, G. C., \& McWilliams, A. (1994). Human resources and Sustained Competitive Advantage: A Resource-based Perspective. The International journal of Human Resource Management, 5(2), 301-326. http://dx.doi.org/10.1080/09585199400000020

Wright, P. M., \& Mc Mahan G. C. (1992). Theoretical perspectives for strategic human resource management. Journal of Management, 18(2), 295-320. http://dx.doi.org/10.1177/014920639201800205

Youndt, M. A., Snell, S. A., Dean, J. W., \& Lepak, D. P. (1996). Human resource management, manufacturing strategy, and performance. Academy of Management Journal, Aug, 39, 836-866. http://dx.doi.org/10.2307/256714

\section{Copyright Disclaimer}

Copyright for this article is retained by the author(s), with first publication rights granted to the journal.

This is an open-access article distributed under the terms and conditions of the Creative Commons Attribution license (http://creativecommons.org/licenses/by/3.0/). 